\title{
Short-Term Efficacy of Calcium Fructoborate on Subjects with Knee Discomfort: a Comparative, Double-Blind, Placebo-Controlled Clinical Study [Corrigendum]
}

\begin{abstract}
Pietrzkowski Z, Phelan M, Keller R, Shu C, Argumedo R, Reyes-Izquierdo T. Clin Interv Aging. 2014;9:895-899.

It has come to the journal's and authors' attention that errors were made during the publication process leading to information being left off the published version that was included in the original drafts. The correct author contribution and funding statements are shown:
\end{abstract}

\section{Author Contributions}

Zbigniew Pietrzkowski directed the study, Michael Phelan performed all data analysis. Robert Keller organized and helped execute clinical protocols in the study. Cynthia Shu and Ruby Argumedo helped in the data analysis and data compilation. Tania Reyes-Izquierdo led the manuscript writing and final edition and functions as the corresponding author.

\section{Funding}

The present study was funded by FutureCeuticals, Inc.

Further to the above the authors also wish to update the disclosure statement:

\section{Disclosure}

At the time of submission, Dr. Pietrzkowski, Dr. ReyesIzquierdo, and Dr. Shu were employed by VDF FutureCeuticals, Inc., which funded the study and supplied the calcium fructoborate that was used in the study. Mr. Keller was employed by NutraClinical, Inc. Dr. Pietrzkowski is a named inventor on several patents relating to calcium fructoborate.

In 2017, following publication, Dove Medical Press which publishes Clinical Interventions in Aging, became part of the Taylor Francis Group, which is a supporter of the All Trials campaign, an initiative that advocates for the registration of all clinical trials. In furtherance of these goals, the journal has requested that the authors retrospectively register the clinical trial reported in this article.
Clinical Interventions in Aging

\section{Publish your work in this journal}

Clinical Interventions in Aging is an international, peer-reviewed journal focusing on evidence-based reports on the value or lack thereof of treatments intended to prevent or delay the onset of maladaptive correlates of aging in human beings. This journal is indexed on PubMed Central, MedLine, CAS, Scopus and the Elsevier
Bibliographic databases. The manuscript management system is completely online and includes a very quick and fair peer-review system, which is all easy to use. Visit http://www.dovepress.com/ testimonials.php to read real quotes from published authors. 